\title{
Forkhead Box Protein C2
}

National Cancer Institute

\section{Source}

National Cancer Institute. Forkhead Box Protein C2. NCI Thesaurus. Code C48221.

Forkhead box protein C2 ( $501 \mathrm{aa}, \sim 53 \mathrm{kDa}$ ) is encoded by the human FOXC2 gene. This protein is involved in the formation of special mesenchymal tissues, and has been isolated in the nucleus. The protein also plays a role in adipocyte metabolism by increasing the sensitivity of the beta-adrenergic cAMP protein kinase A. 